\title{
Money Illusion in Charitable Giving in the Absence of Market Price Resistance
}

\author{
Jorge N. Zumaeta \\ Florida International University, USA \\ jzumaeta@fiu.edu
}

\begin{abstract}
Money illusion occurs when individuals fail to differentiate nominal from real values when making financial and economic decisions. As a consequence, they do not adjust their consumption behavior according to real variables. We report an economic experiment to study whether money illusion appears in a very simple setting. It is very important to mention that the experiment was conducted in the context of charitable giving. Our experimental results showed the absence of money illusion among the participants. Our study suggests that money illusion is not present in the absence of price stickiness (market price resistance). This finding supports Shafir et al. (1997). The main objective of our study is to develop a better understanding of economic agents' charitable giving behaviors as influenced by perceptions of nominal income. Charitable institutions could build fundraising strategies based on behavioral tendencies to the perception of income in nominal or real terms.
\end{abstract}

Keywords: Experimental Economics, Economic Attitudes, Financial Decisions, Money Illusion, Game Theory.

\section{Introduction}

Whether or not money illusion exists on the part of an economic decision-maker is important for economic analysis. For example, while the Keynesian perspective asserts the existence of money illusion and is supported by empirical studies (Orland \& Roos, 2013), Monetarists argued that people were fully rational beings (Lane, 2001; Stockhammer, 2008) accounting for fluctuations in the nominal value of goods and services due to inflation, (even though money illusion is instrumental to Milton Friedman's version of the Phillips curve, as cited in Nelson \& Schwartz, 2008). If money illusion existed, people would have the tendency not to account for changes in the nominal values of goods and services (Eisenhuth, 2017). Shafir et al. (1997) showed that money illusion contributes to price stickiness because nominal prices adjust slower compared to real prices. The Keynesian school argues that money illusion and price stickiness cause a misalignment between nominal prices and real prices (Argitis, 2013). This misalignment causes inflation and allows for the inverse relationship between the inflation rate and the unemployment rate to exist. Kooreman, Faber, and Hofman (2004) identified the presence of money illusion in donations to charities during the introduction of the Euro. They exploited the exogenous replacement of the Guilder by the Euro in the Netherlands. Kooreman et al. compared the revenues of a house-to-house collection for a charity before and after the introduction of the euro collected during 1999, 2000, and 2001 in Guilders to the revenues collected during 2002 and 2003 in Euros.

Kooreman et al. assumed that if there was not a strong presence of money illusion, revenues collected before and after the introduction of the Euro should be about the same in real terms. Kooreman et al. found strong evidence of money illusion, which supported the Keynesian perspective and supplemented the earlier econometric, experimental, and survey evidence. Researchers argued that if a person was subject to money illusion in decision-making, the market might correct such suboptimal behavior after some experience (Fehr \& Tyran, 2007). This is possible in some environments. Researchers assumed that where people engaged in speculation on prices and sought to maximize arbitrage opportunities, they might be immune from money illusion. Nevertheless, empirical evidence showed that nominal variables could influence real activity (Cohen, Polk, \& Vuolteenaho, 2005) in the economy, particularly showing that the three largest stock markets trade at a higher premium when inflation is low compared to when it is high. This aspect aligned with Modigliani and Cohn (1979), who indicated that stock prices showed discounting of future cash flows in nominal terms, rather than with real discount rates. Another concept to take into account is the numerosity effect, which describes how numerical denominations can influence the decision-making process of an individual (see Amado et al., 2007; Gamble, Gärling, Charlton, \& Ranyard, 2002; Raghubir \& Srivastava, 2002). The introduction of the Euro in 2002 translated into a nominal shock at all levels in the economy. Kooreman et al. (2004) and Cannon and Cipriani (2006) showed ways in which donations to charities experienced an increase during the first years when the Euro was introduced. 
British economist A.W. Phillips discovered the Phillips Curve (as cited in Forder, 2015). Phillips studied the annual wage inflation and seasonally adjusted unemployment rates in the United Kingdom from 1860 to 1957 (Blanchard, 2016). His analysis showed an inverse relationship between wage inflation and unemployment. Worldwide, many other economists conducted the same analysis and arrived at similar curves, showing the inverse and stable relationship between these two variables.

\section{Experimental Design, Subject Pool, and Background Data and Donations}

The experiment followed a simple structure and was designed to identify whether individuals made decisions regarding nominal rather than real variables. There are two treatments. Both are equivalent in terms of real variables but differ in terms of nominal variables. Please refer to Appendix B for the procedures adhered to in converting nominal terms to real variables. The experiment was conducted using 81 subjects over eight sessions, approximately 10 subjects for each session. The sessions took place in March and April 2017. They were conducted at the School of Business - the Behavioral Laboratory University of Alberta, in Edmonton, Canada in the spring of 2017. The duration of the study was approximately 30 minutes for each group and participants were compensated for their participation. All participants were volunteers from the University of Alberta's student body. There were two treatments. In the first treatment, called Low Denomination, each individual was endowed with 120 tokens. Tokens were convertible to Canadian dollars at a conversion rate of 8.5 tokens per dollar. In the second treatment, called High Denomination, the endowment was 12,000 tokens, and the conversion rate was 850 tokens per dollar. Participants were required to make a decision on whether to donate part or the entire endowment to a charity. The same request applied to both groups, and the same charities were listed in the form the participants completed.

Those charities included (a) Canadian Red Cross, (b) Habitat for Humanity Canada, (c) Canadian Cancer Society, (d) SickKids Foundation, (e) Animal Rescue Network, and (f) others. Under option (f), participants could write in another charity of their preference. Therefore, depending on the ways in which participants decided to divide the nominal amount, they were compensated for up to 14 Canadian dollars (approximately $\$ 10$ US dollars). It was not possible for a participant to lose money in the experiment. Some information about the treatments and the demographic characteristics of participants is given in Table 1. Forty students participated in the Low Denomination treatment, and 41 partook in High Denomination. Out of the 40 participants playing Low Denomination, $25(62.5 \%)$ were females, and $15(37.5 \%)$ were males. Of the total number of students playing High Denomination, 22 (54\%) were females, and 19 (46\%) were males. Seventythree percent of participants in Low Denomination were majoring in economics or business, while 51\% of students participating in High Denomination were majoring in economics or business. Given the standard deviation of donations (as a percentage of endowment) in our entire data, which was equal to 0.34 compared to a mean of 0.53 , the likelihood of detecting an effect of $1 / 4$ standard deviation is $35 \%$, and of detecting an effect equal to $1 / 2$ of the standard deviation is $89 \%$. These power calculations showed that the sample size was large enough to identify a substantial effect when one exists.

Table 1: Treatments and Characteristics of Participants

\begin{tabular}{|c|c|c|c|c|c|}
\hline Treatment & $\begin{array}{l}\text { Token } \\
\text { Endowment }\end{array}$ & $\begin{array}{l}\text { Conversion } \\
\text { Rate }\end{array}$ & $\begin{array}{c}\text { \# of } \\
\text { Subjects }\end{array}$ & \# Females & $\begin{array}{c}\text { \# Economic/ } \\
\text { Business Majors }\end{array}$ \\
\hline Low Denomination & 120 & $\begin{array}{l}8.5 \text { Tokens } \\
\text { Dollar }\end{array}$ & 40 & 25 & 29 \\
\hline High Denomination & 12,000 & $\begin{array}{l}850 \text { Tokens } \\
\text { Per Dollar }\end{array}$ & 41 & 22 & 21 \\
\hline
\end{tabular}

We made the donations on May 31st, 2017. Donations followed the will of the participants precisely whenever possible. A total of CAD 583.02 was allocated for donations to the charities listed below. Table 2 displays the amount donated to each charity. The interaction between treatment and major is included because it may be the case that students of economics and business are less susceptible to nominal reasoning. Donations were made via the respective charities' web pages using a credit card for payment. Subjects chose a few charities that did not have a working and easily accessible website or mechanism for collecting donations. These entities included Barcelona F.C. (which was not a charity in any case) and Independent Projects for Social Empowerment (see Table 2). 
Table 2: Donations Allocations by Participants (in Canadian Dollars)

Treatment

Low Denomination High Denomination

Canadian Red Cross

$120 / 8.5$

$\mathbf{1 2 0 0 0 / 8 5 0}$

Total

$\$ 54.24$

$\$ 73.36$

$\$ 127.59$

b. Habitat for Humanity Canada

$\$ 16.47$

$\$ 21.18$

$\$ 37.65$

c. Canadian Cancer Society

$\$ 53.02$

$\$ 111.84$

d. SickKids Foundation

$\$ 61.18$

$\$ 114.00$

e. Animal Rescue Network

$\$ 52.82$

$\$ 57.88$

$\$ 124.00$

f. Others:

$\$ 66.12$

$\$ 49.12$

$\$ 67.94$

Church Celebration Edmonton

$\$ 2.35$

Barcelona F.C.

$\$ 2.35$

Doctors without Borders

$\$ 14.12$

Plan Canada International

$\$ 14.12$

Edmonton Hispanic Bilingual Association

$\$ 14.12$

Independent Projects for Social

$\$ 11.76$

Empowerment

Botswana SOS

$\$ 9.12$

Total to Other Non-Profit

$\$ 67.94$

Overall Totals $\$ 403.18 \$ 315.73 \$ 583.02$.

\section{Results and Discussion}

Under the Low Denomination treatment, $15 \%$ of participants kept their entire endowment, and $20 \%$ donated all the money. The average donation in the Low Denomination treatment was $50 \%$ of the endowment. In the High Denomination treatment, $7 \%$ kept all the money, and 24\% donated it all. The average for this treatment was 56\%. Figures 1 and 2 illustrate the frequency distribution of donated dollars by deciles in each treatment. Both figures show some areas of concentration in the distribution of both Low Denomination and High Denomination donations. The averages showed relatively minor differences between the two groups that could not substantiate solidly the existence of money illusion. On the contrary, and in support of the monetarist perspective, the value of each monetary unit did not make a difference in participants' decisions.

Figure 1: Histogram of Donation Decisions in the Low Denomination Condition

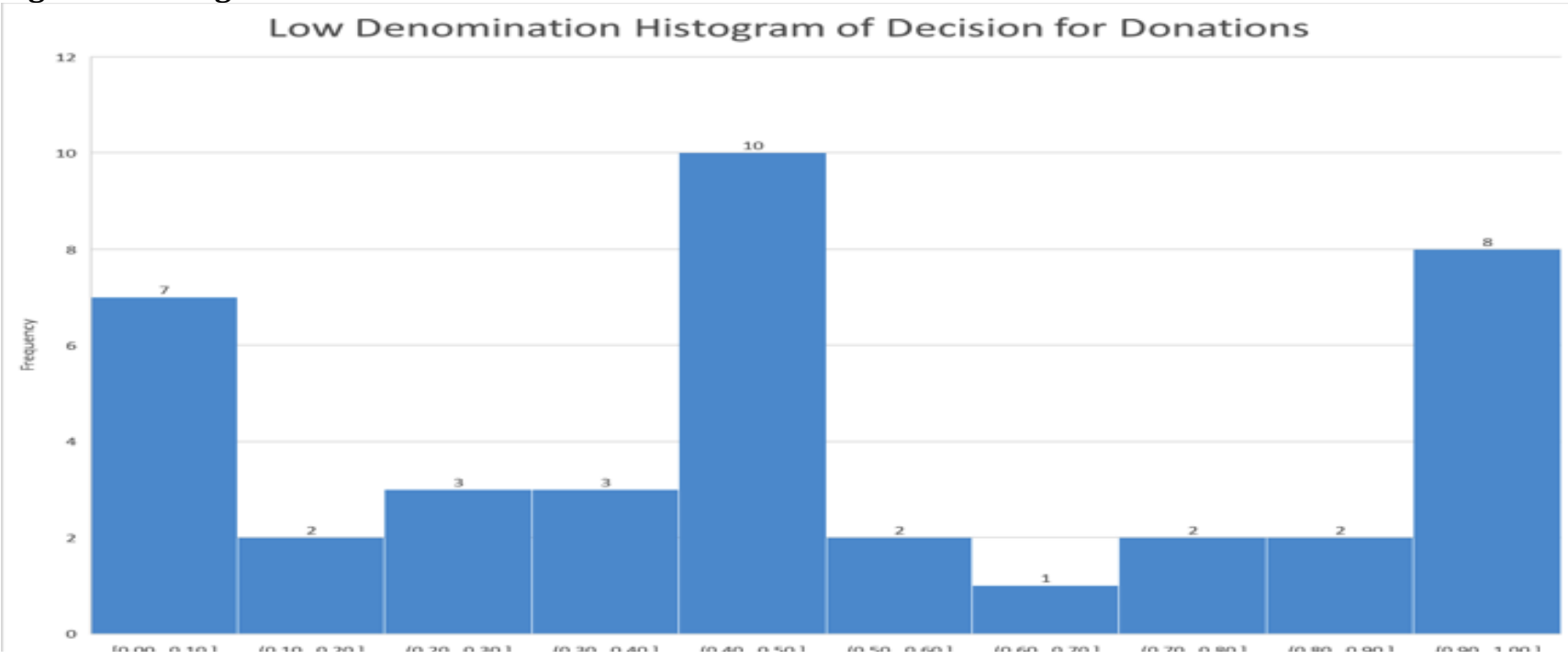


Figure 2: Histogram of Decisions in the High Denomination Condition

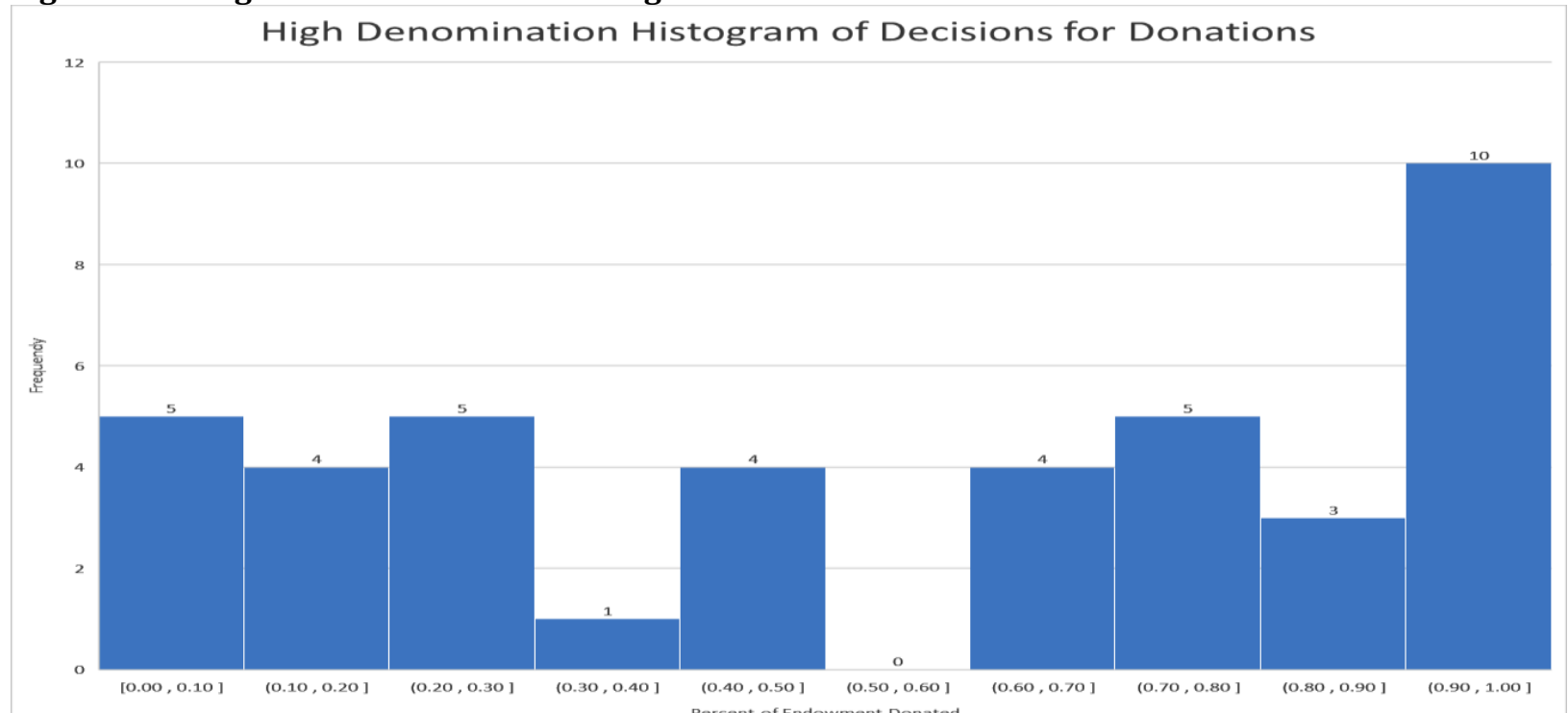

Table 3: Donation by Group and Condition

\begin{tabular}{lllll}
\hline & N & Mean & Std. Deviation & Std. Error Mean \\
\hline Males & 34 & 0.56 & 0.37 & 0.06 \\
Females & 47 & 0.40 & 0.32 & 0.05 \\
Low Denomination & 40 & 0.50 & 0.34 & 0.05 \\
High Denomination & 41 & 0.43 & 0.35 & 0.05 \\
Business Major & 50 & 0.47 & 0.35 & 0.05 \\
Non Business Major & 31 & 0.46 & 0.34 & 0.06 \\
\hline
\end{tabular}

Table 4: Results of t-test of Differences in Percentage Kept between Treatments, Genders, and whether Subjects were Business Majors

\section{T-test for Equality of Means}

\begin{tabular}{llllllll} 
& & & & Mean & \multicolumn{2}{c}{ Std. Error } & \multicolumn{2}{c}{ Difference } \\
& T & df & Sig. (2-tailed) & Difference & Difference & Lower & Upper \\
\hline Gender & 2.085 & 79 & $0.040\left(^{*}\right)$ & 0.159 & 0.076 & 0.007 & 0.312 \\
Treatment & 0.843 & 79 & 0.402 & 0.065 & 0.077 & -0.089 & 0.219 \\
Bus Major & 0.014 & 79 & 0.989 & 0.001 & 0.080 & -0.158 & 0.160 \\
\hline
\end{tabular}

Note: $\left({ }^{*}\right) \mathrm{p}<0.05 ;\left({ }^{* *}\right) \mathrm{p}<0.01$; Gender: Males=1, Females=0; Treatment: Low Denomination $=1$ and High Denomination $=0$; Business/Economic Majors: 1 , Others: 0 .

This finding is supported by $t$-tests (see Table 4). A $t$-test of the hypothesis that the difference in the average percentage of endowment donated between the two treatments showed that the differences were insignificant $(t(79)=0.843, p=.402)$. However, a $t$-test of the hypothesis that women and men donate the same amount on average showed a significant difference in the average percentage of endowment donated between the two genders $(t(79)=2.085, p=.04)$. The null hypothesis that business majors and those that were not business major others donate the same amount was not rejected since the results of the $t$-test showed an insignificant difference $(t(79)=.014, p=.989)$ in the amount donated between these two samples. We also conducted a regression analysis, with donations as the main variable of interest, and controlling for (a) treatment, (b) gender (male/female), (c) major (economic-business/other), and (d) treatment*major. 
The regression analysis is reported in Table 5. In Table 5, Column 1 shows the regression analysis of donations as a function of treatment. Column 2 shows the regression analysis when controlling for treatment and gender. Column 3 contains the estimates for a specification consisting of treatment, gender, Business major, and treatment*major. The interaction between treatment and major is included because it may be the case that students of economics and business are less susceptible to nominal reasoning. The analysis showed no statistical significance, except for gender. Table 5 presents regression estimates. Donations are the dependent variable. When controlling only for treatment, in equation (1), the regression analysis did not show any statistical significance. In other words, the data showed no indication of the existence of the money illusion effect between the two treatments. When controlling for gender in equation (2), the regression analysis showed that treatment did not have any statistically significant effect on the amount donated. The regression analysis did not show any significant presence of money illusion as treatment remains insignificant.

In specification (3), we, also controlled for gender, treatment, business/economics major, and interaction effect of treatment $*$ business. As with the prior results, the data showed that gender was statistically significant, which remained consistent with prior studies? Overall, none of the other variables of treatment, business/economics major and interaction effect of treatment * business, showed any significance towards explaining the relationship between the dependent variable (donations) and the independent variables (treatment, business/economics major, and treatment * business/economics majors). There is a significant positive effect on females on the amount donated. A $t$-test also shows a significant difference in the average percentage of endowment donated between the two gender groups $(t=2.085, p=.040)$. Furthermore, running the auxiliary regressions for males and females separately, as reported in Table 6, showed no effect of treatment, business/economics major, and interaction effect of treatment * business on the amount donated.

Table 5: Determinants of Donations

\begin{tabular}{llll}
\hline & $\begin{array}{l}\text { (1) } \\
\text { Donation }\end{array}$ & $\begin{array}{l}\mathbf{( 2 )} \\
\text { Donation }\end{array}$ & $\begin{array}{l}\text { (3) } \\
\text { Donation }\end{array}$ \\
\hline Gender & & $.167\left(^{*}\right)$ & $.167\left(^{*}\right)$ \\
& & $(.077)$ & $(.078)$ \\
Treatment & .065 & 0.080 & -.120 \\
& $(.077)$ & $(.076)$ & $(.129)$ \\
Business/Economics & & & -.007 \\
Major & & & $(.107)$ \\
Treatment*Business/ & & & -.057 \\
Economics Major & & & $0.107)$ \\
Constant & $.568(* * *)$ & $.645\left(^{* * *}\right)$ & $.649(* * *)$ \\
& $(.054)$ & $(.064)$ & $(.084)$ \\
$\mathrm{R}^{2}$ & & & \\
Observations & .009 & 81 & .065 \\
\hline
\end{tabular}

Note: $\left({ }^{*}\right) \mathrm{p}<0.05 ;\left({ }^{* *}\right) \mathrm{p}<0.01$; Gender: Males=1, Females=0; Treatment: Low Denomination $=1$ and High Denomination = 0; Business/Economic Majors: 1, Others: 0; Treatment/Business: 1, Others: 0 . 


\begin{tabular}{|c|c|c|}
\hline \multicolumn{3}{|c|}{$\begin{array}{l}\text { Journal of Economics and Behavioral Studies (ISSN: 2220-6140) } \\
\text { Vol. 13, No. 3, pp. 24-33, June 2021 }\end{array}$} \\
\hline & $\begin{array}{l}\text { For Males } \\
\text { Donation }\end{array}$ & $\begin{array}{l}\text { For Females } \\
\text { Donation } \\
(2)\end{array}$ \\
\hline Treatment & $\begin{array}{l}.120 \\
(225)\end{array}$ & $\begin{array}{l}.096 \\
(.155)\end{array}$ \\
\hline Business/Economics Major & $\begin{array}{l}-.154 \\
(.172)\end{array}$ & $\begin{array}{l}.117 \\
(.137107)\end{array}$ \\
\hline $\begin{array}{l}\text { Treatment*Business/ Economics } \\
\text { Major }\end{array}$ & $\begin{array}{l}.041 \\
(.278)\end{array}$ & $\begin{array}{l}.028 \\
(0.198)\end{array}$ \\
\hline Constant & $\begin{array}{l}.337 \\
(.394)\end{array}$ & $\begin{array}{l}.379 \\
(.271)\end{array}$ \\
\hline $\mathrm{R}^{2}$ & .061 & .046 \\
\hline Observations & 33 & 46 \\
\hline
\end{tabular}

Note: $\left({ }^{*}\right) \mathrm{p}<0.05 ;\left({ }^{* *}\right) \mathrm{p}<0.01$; Gender: Males=1, Females=0; Treatment: Low Denomination $=1$ and High Denomination $=0$; Business /Economic Majors: 1, Others: 0; Treatment/Business: 1, Others: 0.

\section{Discussion}

The discussion regarding whether money illusion influences individuals' decision-making and consumer behavior remain vigorous (Nelson \& Schwartz, 2008; Stockhammer, 2008). However, the effect of money illusion on consumers' decision-making and behavior is difficult to distinguish from other factors with nonexperimental data due to the dynamic changes typically occurring in an individual's decision environment. The results of the experiment were straightforward and showed minimal to non-existent money illusion among the participating individuals. It might seem that the results support the Monetarist school of thought, and participants understood clearly the difference between nominal and real variables, thereby adjusting their consumption behavior accordingly (in the short run). This is consistent with Shafir et al.'s (1997) intuition that money illusion influenced consumers' behavior through price stickiness, occurring because people fail to anticipate and then to account for price changes (Maloney, 2011; Stockhammer, 2008). In this particular experiment, there were no price changes since prices were varied between-subject, and money illusion was not observed. The experiment shows that the denomination of monetary units used for decisionmaking does not have any effect on decisions. There was no evidence of any numerosity effect. The minor differences in decisions between the two treatments were not statistically significant. We observed that participants were attentive to requests of dividing the tokens and calculating the equivalent amount in dollars. We found several calculations on participants' scratch paper utilizing the conversion rate from tokens to dollars. In addition, there were many inquiries about ways in which the donations would be made to the agency of their choice.

Such observations support the idea that our subjects thought rationality to arrive at an informed decision (Cárdenas, De Roux, Jaramillo, \& Martinez, 2014). As we stated earlier, central to the argument of the Phillips Curve is the existence of the money illusion effect, in which individuals make decisions based on nominal rather than real variables. This influences consumer behavior through wage or price stickiness, insufficient adjustment of prices and wages to the growth of the money supply. For example, if nominal wages remain the same, even though real wages fall, consumers may spend as much as before, but not realize that they actually have a less real income. The money illusion effect, though price stickiness, is one of the factors contributing to the slow adjustment of consumer behavior to real price changes in the market, as consumer behavior and demand do not adjust automatically with price fluctuations. Price inertia is also the mechanism underlying the persistence of shocks and business cycles in New Keynesian Dynamic Stochastic General Equilibrium models. In other words, the tendency of prices to remain constant, despite changes in the cost of producing and selling a product, can cause general inflationary pressure in the market. Above all, the experiment rendered clear results that did not show a significant indication of money illusion, which did not have any 
impact on individuals' decision-making in terms of charity giving. There was no indication of money illusion in our one-shot task (one treatment), where there could be no role for price stickiness in generating money illusion. This suggests that a previous history of decision-making and some inertia in these decisions are the key factors leading to money illusion.

\section{Conclusion and Recommendations}

Our experimental results revealed the absence of money illusion among the participants. Our study showed that in an environment where price stickiness was not possible, money illusion was not observed, perhaps suggesting a relationship of causality. Such observation is congruent with the findings of Shafir et al. (1997), who argue that money illusion can only be observed when there is price stickiness. The conjecture that is suggested from this study is that money illusion arises only as a consequence of inertia in decision making when real, but not nominal variables, change. One recommendation would be to incentivize researchers to engage in multi-treatment long-term experiments to better gauge economic agents' behavioral and financial decisions over time. A one-shot task may provide a limited glimpse of the economic attitudes and financial decisions with respect to charitable giving. During our one-shot economic experiment, participants did not exhibit money illusion characteristics because there was no price stickiness; nevertheless, participants responded to the experiments based on their own prior experiences and cultural biases. A second recommendation would be for future researchers to expand on the limitations on economic agents' charitable giving behaviors as influenced by perceptions of nominal income. This information is important since one of the objectives of this analysis is to determine a way of motivating economic agents to participate actively in charitable giving. As indicated earlier, charitable institutions could build fundraising strategies based on behavioral tendencies in response to the perception of income in nominal or real terms.

\section{References}

Amado, S., Teközel, M., Topsever, Y., Ranyard, R., Del Missier, F. \& Bonini, N. (2007). Does “000,000" matter? Psychological effects of Turkish monetary reform. Journal of Economic Psychology, 28(2), 154-169.

Argitis, G. (2013). The illusions of the "new consensus" in macroeconomics: A Minskian analysis. Journal of Post Keynesian Economics, 35(3), 483-505.

Blanchard, 0. (2016). The Phillips Curve: Back to the '60s? American Economic Review, 106(5), 31-34.

Cárdenas, J. C., De Roux, N., Jaramillo, C. R. \& Martinez, L. R. (2014). Is it my money or not? An experiment on risk aversion and the house-money effect. Experimental Economics, 17(1), 47-60.

Cannon, E. S. \& Cipriani, G. P. (2006). Euro-illusion: A natural experiment. Journal of Money, Credit, and Banking, 38(5), 1391-1403.

Cohen, R. B., Polk, C. \& Vuolteenaho, T. (2005). Money illusion in the stock market: The Modigliani-Cohn hypothesis. The Quarterly Journal of Economics, 120(2), 639-668.

Eisenhuth, R. (2017). Money illusion and market survival. Macroeconomic Dynamics, 21(1), 1-10.

Fehr, E. \& Tyran, J. R. (2007). Money illusion and coordination failure. Games and Economic Behavior, 58(2), 246-268.

Forder, J. (2015). Textbooks on the Phillipps Curve. History of Political Economy, 47(2), 207-240.

Gamble, A., Gärling, T., Charlton, J. \& Ranyard, R. (2002). Euro illusion: Psychological insights into price evaluations with the unitary currency. European Psychologist, 7, 302-311.

Kooreman, P., Faber, R. P. \& Hofmans, H. M. (2004). Charity donations and the euro introduction: Some quasiexperimental evidence on money illusion. Journal of Money, Credit, and Banking, 36(6), 1121-1124.

Lane, J. (2001). The political economy of Switzerland: A monetarist success? West European Politics, 24(2), 191-210.

Maloney, J. (2011). Straightening the Phillipps Curve, 1968-1976. The European Journal of the History of Economic Thought, 18(3), 407-440.

Modigliani, F. \& Cohn, R. A. (1979). Inflation, rational valuation, and the market. Financial Analysts Journal, 35(2), 24-44.

Nelson, E. \& Schwartz, A. J. (2008). The impact of Milton Friedman on modern monetary economics: Setting the record straight on Paul Krugman's “Who Was Milton Friedman?" Journal of Monetary Economics, 55(4), 835-856. 


\begin{tabular}{l} 
Journal of Economics and Behavioral Studies (ISSN: 2220-6140) \\
Vol. 13, No. 3, pp. 24-33, June 2021 \\
\hline \hline
\end{tabular}

Orland, A. \& Roos, M. W. M. (2013). The new Keynesian Phillipps Curve with myopic agents. Journal of Economic Dynamics \& Control, 37(11), 22-70.

Raghubir, P. \& Srivastava, J. (2002). Effect of face value on product valuation in foreign currencies. Journal of Consumer Research, 29, 335-347.

Shafir, E., Diamond, P. \& Tversky, A. (1997). Money illusion. The Quarterly Journal of Economics, 112(2), 341374.

Stockhammer, E. (2008). Is the Nairu theory a monetarist, new Keynesian, -Post Keynesian, or a Marxist theory? Metroeconomica, 59(3), 479-510.

\section{Appendix A1. Low Denomination - Instructions to Subjects}

Instructions for the Experiment: Today you will participate in an economic experiment where you get to decide on how to split 120 tokens between yourself and a charity. The conversion rate is 8.5 tokens per dollar. You can keep the entire amount, donate a portion and keep the rest, or donate the entire amount. If you decide to donate a portion or the entire amount, the researcher will donate the amount to the agency/organization you have chosen or you can keep the entire amount. If you decide to keep a portion or the entire amount, the researcher will give you the money in cash at the end of this session. You can choose from 5 charities that we have indicated in options a) - e) below

Please write your decision:

Tokens to be kept:

Tokens to be donated:

Please choose by circling the agency/organization that you would like to donate to:

a) Canadian Red Cross

b) Habitat for Humanity Canada

c) Canadian Cancer Society

d) SickKids Foundation

e) Animal Rescue Network

f) Other: Please fill in the blank

This concludes the experiment. Thank you for your participation.

\section{Appendix A2. High Denomination - Instructions to Subjects}

Instructions for the Experiment: Today you will participate in an economic experiment where you get to decide on how to split 12000 tokens between yourself and a charity. The conversion rate of tokens to dollars is 850 tokens per dollar. You can keep the entire amount, donate a portion and keep the rest, or donate the entire amount. If you decide to donate a portion or the entire amount, the researcher will make a donation in the amount to the agency/organization you have chosen or you can keep the entire amount. If you decide to keep a portion or the entire amount, the researcher will give you the money in cash at the end of this session. You can choose from 5 charities that we have indicated in options a) - e) below

Please write your decision:

Tokens to be kept:

Tokens to be donated:

Please choose by circling the agency/organization that you would like to donate to:

a) Canadian Red Cross

b) Habitat for Humanity Canada

c) Canadian Cancer Society

d) SickKids Foundation

e) Animal Rescue Network

f) Other: Please fill in the blank

This concludes the experiment. Thank you for your participation. 


\section{Appendix B1: Raw Data - Low Denomination}

\begin{tabular}{|c|c|c|c|c|c|c|c|c|}
\hline \multicolumn{9}{|c|}{120 Tokens - 8.5 Tokens per Dollar } \\
\hline \multirow{2}{*}{ Participant } & \multicolumn{2}{|c|}{ Tokens } & \multicolumn{4}{|c|}{ Money } & \multirow[b]{2}{*}{ Gender } & \multirow[b]{2}{*}{ Major } \\
\hline & Kept & Donated & & & & ted & & \\
\hline 1 & 0 & 120 & $\$$ & - & $\$$ & 14 & $\mathrm{~F}$ & Arts \\
\hline 2 & 90 & 30 & $\$$ & 11 & $\$$ & 4 & $\mathrm{~F}$ & Psychology \\
\hline 3 & 20 & 100 & $\$$ & 2 & $\$$ & 12 & $\mathrm{~F}$ & Management \\
\hline 4 & 48 & 72 & $\$$ & 6 & $\$$ & 8 & $\mathrm{~F}$ & Engineer \\
\hline 5 & 30 & 90 & $\$$ & 4 & $\$$ & 11 & $\mathrm{~F}$ & Human Resources \\
\hline 6 & 120 & & $\$$ & 14 & $\$$ & - & $M$ & Business \\
\hline 7 & 70 & 50 & $\$$ & 8 & $\$$ & 6 & $\mathrm{~F}$ & Finance \\
\hline 8 & 51 & 69 & $\$$ & 6 & $\$$ & 8 & $\mathrm{~F}$ & Business \\
\hline 9 & 60 & 60 & $\$$ & 7 & $\$$ & 7 & $M$ & Management \\
\hline 10 & 100 & 20 & $\$$ & 12 & $\$$ & 2 & $\mathrm{~F}$ & Veterinary \\
\hline 11 & 120 & & $\$$ & 14 & $\$$ & - & $M$ & Business \\
\hline 12 & 40 & 80 & $\$$ & 5 & $\$$ & 9 & $\mathrm{~F}$ & Business \\
\hline 13 & 60 & 60 & $\$$ & 7 & $\$$ & 7 & $\mathrm{~F}$ & Finance \\
\hline 14 & 60 & 60 & $\$$ & 7 & $\$$ & 7 & $\mathrm{~F}$ & Business \\
\hline 15 & 80 & 40 & $\$$ & 9 & $\$$ & 5 & $\mathrm{~F}$ & Intl Business \\
\hline 16 & 90 & 30 & $\$$ & 11 & $\$$ & 4 & $\mathrm{~F}$ & Nursing \\
\hline 17 & 30 & 90 & $\$$ & 4 & $\$$ & 11 & $\mathrm{~F}$ & Finance \\
\hline 18 & 120 & & $\$$ & 14 & $\$$ & - & $\mathrm{F}$ & Business \\
\hline 19 & 120 & & $\$$ & 14 & $\$$ & - & $M$ & Computer Science \\
\hline 20 & 80 & 40 & $\$$ & 9 & $\$$ & 5 & $M$ & Computer Science \\
\hline 21 & 120 & & $\$$ & 14 & $\$$ & - & $M$ & Finance \\
\hline 22 & 110 & 10 & $\$$ & 13 & $\$$ & 1 & $\mathrm{~F}$ & Natural Sciences \\
\hline 23 & 80 & 40 & $\$$ & 9 & $\$$ & 5 & $\mathrm{~F}$ & Marketing \\
\hline 24 & 60 & 60 & $\$$ & 7 & $\$$ & 7 & $M$ & Business \\
\hline 25 & 0 & 120 & $\$$ & - & $\$$ & 14 & $\mathrm{~F}$ & Business \\
\hline 26 & 60 & 60 & $\$$ & 7 & $\$$ & 7 & $M$ & Business \\
\hline 27 & 60 & 60 & $\$$ & 7 & $\$$ & 7 & $\mathrm{~F}$ & Business \\
\hline 28 & 60 & 60 & $\$$ & 7 & $\$$ & 7 & $\mathrm{M}$ & Management \\
\hline 29 & 103 & 17 & $\$$ & 12 & $\$$ & 2 & $F$ & Operations Management \\
\hline 30 & 0 & 120 & $\$$ & - & $\$$ & 14 & $M$ & Business \\
\hline 31 & 120 & 0 & $\$$ & 14 & $\$$ & - & $\mathrm{M}$ & Business \\
\hline 32 & 0 & 120 & $\$$ & - & $\$$ & 14 & $\mathrm{~F}$ & Business \\
\hline 33 & 0 & 120 & $\$$ & - & $\$$ & 14 & $\mathrm{~F}$ & Business \\
\hline 34 & 12 & 108 & $\$$ & 1 & $\$$ & 13 & $\mathrm{~F}$ & Business \\
\hline 35 & 60 & 60 & $\$$ & 7 & $\$$ & 7 & $M$ & Economics \\
\hline 36 & 0 & 120 & $\$$ & - & $\$$ & 14 & $\mathrm{~F}$ & Biology \\
\hline 37 & 0 & 120 & $\$$ & - & $\$$ & 14 & $\mathrm{~F}$ & Business \\
\hline 38 & 84 & 36 & $\$$ & 10 & $\$$ & 4 & $M$ & Economics \\
\hline 39 & 60 & 60 & $\$$ & 7 & $\$$ & 7 & $M$ & Arts \\
\hline 40 & 0 & 120 & $\$$ & - & $\$$ & 14 & $\mathrm{M}$ & Physics \\
\hline
\end{tabular}




\section{Appendix B2: Raw Data - High Denomination}

\begin{tabular}{|c|c|c|c|c|c|c|c|c|}
\hline \multicolumn{9}{|c|}{12,000 Tokens $-8,500$ Tokens per Dollar } \\
\hline \multirow{2}{*}{ Participant } & \multicolumn{2}{|c|}{ Tokens } & \multicolumn{4}{|c|}{ Money } & \multirow[b]{2}{*}{ Gender } & \multirow[b]{2}{*}{ Major } \\
\hline & Kept & Donated & & & & & & \\
\hline 1 & 4,000 & 8,000 & $\$$ & 5 & $\$$ & 9 & $\mathrm{~F}$ & Education \\
\hline 2 & 12,000 & - & $\$$ & 14 & $\$$ & - & $\mathrm{M}$ & Education \\
\hline 3 & 4,000 & 8,000 & $\$$ & 5 & $\$$ & 9 & $\mathrm{~F}$ & Nutrition \\
\hline 4 & 6,000 & 6,000 & $\$$ & 7 & $\$$ & 7 & $\mathrm{~F}$ & Public Administration \\
\hline 5 & 6,000 & 6,000 & $\$$ & 7 & $\$$ & 7 & $\mathrm{~F}$ & Hospitality \\
\hline 6 & 12000 & - & $\$$ & 14 & $\$$ & - & $\mathrm{M}$ & Business \\
\hline 7 & 3500 & 8,500 & $\$$ & 4 & $\$$ & 10 & $\mathrm{~F}$ & Business \\
\hline 8 & 2550 & 9,450 & $\$$ & 3 & $\$$ & 11 & $\mathrm{M}$ & Computer Science \\
\hline 9 & 10285 & 1,715 & $\$$ & 12 & $\$$ & 2 & $\mathrm{~F}$ & Business \\
\hline 10 & 11150 & 850 & $\$$ & 13 & $\$$ & 1 & $\mathrm{M}$ & Business \\
\hline 11 & 4248 & 7,752 & $\$$ & 5 & $\$$ & 9 & $\mathrm{~F}$ & Business \\
\hline 12 & 3500 & 8,500 & $\$$ & 4 & $\$$ & 10 & $\mathrm{~F}$ & Chemistry \\
\hline 13 & 8500 & 3,500 & $\$$ & 10 & $\$$ & 4 & $\mathrm{~F}$ & Occupational Therapy \\
\hline 14 & 6000 & 6,000 & $\$$ & 7 & $\$$ & 7 & $\mathrm{~F}$ & Nursing \\
\hline 15 & & 12,000 & $\$$ & - & $\$$ & 14 & $\mathrm{~F}$ & Graphic Design \\
\hline 16 & 8500 & 3,500 & $\$$ & 10 & $\$$ & 4 & $\mathrm{M}$ & Business \\
\hline 17 & 6000 & 6,000 & $\$$ & 7 & $\$$ & 7 & $\mathrm{M}$ & Engineering \\
\hline 18 & 11000 & 1,000 & $\$$ & 13 & $\$$ & 1 & $\mathrm{M}$ & Arts \\
\hline 19 & & 12,000 & $\$$ & - & $\$$ & 14 & $\mathrm{~F}$ & Business \\
\hline 20 & 8500 & 3,500 & $\$$ & 10 & $\$$ & 4 & $\mathrm{M}$ & Science \\
\hline 21 & 10200 & 1,800 & $\$$ & 12 & $\$$ & 2 & $\mathrm{~F}$ & Economics \\
\hline 22 & 8500 & 3,500 & $\$$ & 10 & $\$$ & 4 & $\mathrm{~F}$ & Bio-Chemistry \\
\hline 23 & 8500 & 3,500 & $\$$ & 10 & $\$$ & 4 & $\mathrm{M}$ & International Business \\
\hline 24 & 10,300 & 1,700 & $\$$ & 12 & $\$$ & 2 & $\mathrm{M}$ & Finance \\
\hline 25 & 10000 & 2,000 & $\$$ & 12 & $\$$ & 2 & $\mathrm{~F}$ & Biology \\
\hline 26 & 7750 & 4,250 & $\$$ & 9 & $\$$ & 5 & $\mathrm{~F}$ & Marketing \\
\hline 27 & & 12,000 & $\$$ & - & $\$$ & 14 & $\mathrm{M}$ & Management \\
\hline 28 & 3400 & 8,600 & $\$$ & 4 & $\$$ & 10 & $\mathrm{M}$ & Physics \\
\hline 29 & 0 & 12,000 & $\$$ & - & $\$$ & 14 & $\mathrm{~F}$ & Business \\
\hline 30 & 2000 & 10,000 & $\$$ & 2 & $\$$ & 12 & $\mathrm{~F}$ & Business \\
\hline 31 & 12000 & - & $\$$ & 14 & $\$$ & - & $\mathrm{M}$ & Business \\
\hline 32 & 0 & 12,000 & $\$$ & - & $\$$ & 14 & $\mathrm{~F}$ & Business \\
\hline 33 & 0 & 12,000 & $\$$ & - & $\$$ & 14 & $\mathrm{~F}$ & Business \\
\hline 34 & 0 & 12,000 & $\$$ & - & $\$$ & 14 & $\mathrm{M}$ & Modern Languages \\
\hline 35 & 2000 & 10,000 & $\$$ & 2 & $\$$ & 12 & $M$ & Physics \\
\hline 36 & 0 & 12,000 & $\$$ & - & $\$$ & 14 & $\mathrm{~F}$ & Engineering \\
\hline 37 & 4,250 & 7,750 & $\$$ & 5 & $\$$ & 9 & $M$ & Economics \\
\hline 38 & 0 & 12,000 & $\$$ & - & $\$$ & 14 & $\mathrm{M}$ & MBA \\
\hline 39 & 2000 & 10,000 & $\$$ & 2 & $\$$ & 12 & $M$ & Business \\
\hline 40 & 3000 & 9,000 & $\$$ & 4 & $\$$ & 11 & $\mathrm{~F}$ & Business \\
\hline 41 & 0 & 12,000 & $\$$ & - & $\$$ & 14 & $M$ & Arts \\
\hline
\end{tabular}

